\title{
Menakar Kembali Materi Pendidikan Agama Islam Untuk Menangkal Tuduhan Faham Radikalisme Kepada Umat Islam
}

\author{
Ulyan Nasri \\ ulyannasri@gmail.com \\ IAI Hamzanwadi NW Lombok Timur
}

\begin{abstract}
Abstrak:
Istilah radikalisme sudah menjadi istilah yang familer dilekatkan pada suatu kelompok dalam Islam. Indikator-indikator untuk menyebut kelompok dalam Islam radikalisme di antaranya adalah terorisme, anarkis, pemberontak dan ekstrim. Salah satu penyebab terjebaknya oknum kepada prilaku radikalisme yaitu pemahaman agama yang parsial dan cenderung kepada sifat fanatisme. Sifat inilah yang kemudian mengakibatkan rasa superioritas atas pemeluk agama lain. Gagal faham tentang konsep jihad dalam agama menjadikan seseorang mengambil jalan pintas yaitu dengan menebar teror kepada orangorang yang justru tidak bersalah. konsekuensi logis dari interpretasi ini adalah penyandingan terorisme sebagai buah dari radikalisme. Hipotesa ini adalah sesuatu yang wajar, mengingat berbagai aktivitas teror di berbagai belahan dunia senantiasa mengatasnamakan jihad yang dilakukan umat Islam sebagai bentuk ketaatan kepada Tuhan. Hal ini menimbulkan berbagai gejolak yang tanpa disadari tidak hanya berimplikasi pada menurunnya stabilitas nasional, tapi bahkan menyulut respon negatif dari berbagai belahan dunia. Oleh karena itu diperlukan adanya pemahaman inklusif terhadap agama sehingga pemeluk agama menyadari bahwa pluralitas adalah sebuah keniscayaan. Melihat permasalahan tersebut, perlu ada penguatan dan penegasan kembali tentang originalitas ajaran Islam yang mengandung nilai-nilai humanis-pluralistik dan toleran. Maka, peran yang sangat strategis dalam hal ini adalah materi pendidikan agama Islam harus mampu merekonstruksi materi-materi yang yang relevan untuk menangkal tuduhan tersebut. Pada titik inilah fokus kajian dalam artikel ini yaitu berusaha menakar kembali materi-materi pendidikan agama Islam yang cenderung bernilai humanispluralis dan toleran untuk menangkal tuduhan radikalisme pada agama Islam.
\end{abstract}

Kata Kunci: Materi Pendidikan Agama Islam, Faham Radikalisme

\section{Pendahuluan}

Faham radikalisme ${ }^{1}$ yang dituduhkan pada agama Islam sudah terlanjur melekat dalam pribadi umat Islam. Apabila ditelisik secara kritis-konstruktif makna radikal ini justru memiliki arti yang berbeda seperti yang difahami oleh kebanyakan orang. Contoh dalam

${ }^{1}$ Radikal dari segi etimologi berasal dari kata "radix" artinya akar. Istilah radikal apabila dijelaskan Secara terminology dalam filsafat berarti berpikir secara mendalam sampai ke akar-akar permasalahan, sehingga terkuak mutiara hikmah di balik yang wujud (yang diteliti). Lihat Ulyan Nasri, Menjemput Ilmu: sebuah Pengantar Filsafat Ilmu (Yogyakarta: Semesta Ilmu, 2016). Baca juga Ulyan Nasri, Bersahabat dengan Ilmu: Sebuah Pengantar Filsafat Ilmu (Mataram: CV. Haramain Lombok, 2018). 
filsafat, istilah radikal ini cenderung berkononatsi positif, karena radikal dalam filsafat merupakan salah satu di antara ciri-ciri berpikir filsafat yang berpotensi untuk melahirkan ilmu pengetahuan. Tapi, apabila radikalisme ini diletakkan pada umat Islam pasti berkonotasi negatif yang cenderung mengarah kepada terorisme, pembrontak, anarkis dan ekstermis. $^{2}$

Negara Indonesia merupakan Negara plural dan heterogen, dan memiliki potensi kekayaan multietnis, mutikultural, multi agama yang kesemuanya merupakan potensi untuk membangun negara multikultural yang besar. Indonesia terdiri atas sejumlah besar kelompok-kelompok etnis, budaya, agama, dan lain-lain yang masing-masing plural (jamak) dan sekaligus juga heterogen. ${ }^{3}$

Pada dasarnya agama apapun memiliki kecenderungan untuk melakukan truth claim (mengkalim sebagai yang paling benar) karena agama merupakan nilai kepercayaan yang harus dipegang teguh oleh pemeluknya, sikap truth claim tersebaut akan bernilai positif apabila hanya dioreintasikan ke dalam (intrinsic Orientation) dalam penghayatan dan aplikasinya, bukan untuk keluar dirinya (ekstrinsic orientation) yang menyebabkan prasangka negatif dan konflik. Agama Intrinsik memenuhi seluruh hidup dengan motivasi dan makna, sedang agama ektrinsik menjadikan agama diperbudak untuk mendukung dan membenarkan kepentingan pribadi. ${ }^{4}$ Apabila praktik agama mengarah pada truth claim yang mengasingkan terhadap kebenaran lainnya, maka sikap yang demikian dalam pandangan Kimball, sama halnya dengan melakukan pembusukan terhadap agama. ${ }^{5}$ Tujuan pendidikan Islam adalah untuk membentuk manusia paripurna (insan kamil), tujuan tersebut merupakan tujuan tertinggi dari pendidikan Islam sebab sesuai dengan tujuan hidup manusia, dan peranannya sebagai makhluk ciptaan Allah. Indikator dari insan kamil adalah pertama: Menjadi hamba Allah, kedua: mengantarkan subjek didik menjadi khalifah Allah fi al-ardh, dan yang ketiga: adalah untuk memperoleh kesejahteraaan dan kebahagiaan di dunia dan akhirat, baik individu maupun masyarakat. ${ }^{6}$ Namun, tujuan mulia tersebut akan terasa sulit untuk bisa dicapai

${ }^{2}$ Ulyan Nasri, Mengenal Ahl al-Sunnah wa al-Jama'ah dalam Konteks Nahdlatul Wathan (Mataram: CV. Haramain Lombok, 2019), cet. Ke-4, hlm. 41. Baca juga Ulyan Nasri, Philosophy is Mother of Science: Pengantar Filsafat (Mataram: CV. Haramain Lombok, 2020). Bandingkan Ulyan Nasri, Ngaji Bareng Filosof: Sebuah Pengantar Filsafat Umum (Mataram: CV. Haramain Lombok, 2020).

3 B.Kusumohamidjojo, Kebinekaan Masyarakat Indonesia; Suatu Problematik Filsafat Kebudayaan (Jakarta; Grasindo, 2000), 45.

${ }^{4}$ Moh.Roqib, Ilmu Pendidikan Islam Pengembangan pendidikan Integratif di Sekolah Keluarga dan Masyarakat, (Yogyakarta;LKis, 2009), 189.

${ }^{5}$ Syamsul arifin, Studi Islam Kontemporer; Arus Radikalisme dan Multikulturalisme di Indonesia (Malang: Intrans Publising, 2015), 10 2020). 43 .

${ }^{6}$ Baca juga Ulyan Nasri, Philosophy is Mother of Science: Pengantar Filsafat (Mataram: CV. Haramain Lombok, 
sepanjang hayat manusia, apabila dicemari oleh pemikiran, wacana, dan gagasan-gagasan yang menyesatkan. Maka pembelajara Pendidikan Agama Islam baik dalam pendidikan Formal dan non formal hendaknya dapat menjawab tantangan tersebut. Dan memang Pendidikan Islam sendiri telah eksis dan memiliki karakteristik yang khas, khususnya dalam diskursus pendidikan di Indonesia. ${ }^{7}$

Faham radikalisme yang sudah terlanjur dilekatkan pada ajaran Islam dan pemeluknya-untuk tidak mengatakan-Islam adalah agama terorisme yang mengajarkan kekerasan, pembrontakan, peperangan dan tidak toleran menjadi fokus kajian dalam tulisan ini. Inilah menjadi kegelisahan akademik dari tulisan ini yang berusaha merekonstruksi kembali ajaran Islam yang mengandung nilai-nilai humanis, pluralis, dan sosialis dalam arti Islam adalah agama yang cinta damai, toleran kepada agama lain dan cenderung mengajarkan kasih sayang kepada semua manusia. Tidak hanya itu, semua makhluk pun dituntut harus disayangi. Nilai-nilai positif inilah yang berusaha dikaji kembali dan dipublikasikan supaya tuduhan radikalisme kepada Islam dapat diredam. Di mulai dari materi-materi ajar pada mata pelajaran agama Islam, perlu mendapat perhatian serius kepada semua guru di semua jenjang sekolah.

Reinterpretasi Istilah Radikalisme

Sepanjang yang kita baca dari referensi-referensi yang ada, belum kita temukan bahwa radikalisme tertuju pada suatu ajaran agama, apalagi ditujukan secara khusus kepada Islam. Akan tetapi kebanyakan definisi mengkaitkannya dengan politik. Berikut ini kita nukilkan tentang pengertian Radikalisme: "Radikalisme (dari bahasa Latin radix yang berarti "akar") adalah istilah yang digunakan pada akhir abad ke-18 untuk pendukung Gerakan Radikal. Dalam sejarah, gerakan yang dimulai di Britania Raya ini meminta reformasi sistem pemilihan secara radikal. Gerakan ini awalnya menyatakan dirinya sebagai partai kiri jauh yang menentang partai kanan jauh. Begitu "radikalisme" historis mulai terserap dalam perkembangan liberalisme politik, pada abad ke-19 makna istilah radikal di Britania Raya dan Eropa daratan berubah menjadi ideologi liberal yang progresif". 8

Melalui penjelasan di atas dapat kita simpulkan bahwa asal muasal tindakan radikal muncul dari salah satu aliran politik bukan dari ajaran agama tertentu. Dengan kata lain dapat pula kita nyatakan bahwa gerakan radikal tidak bersumber dari ajaran agama. Namun bisa saja terjadi kesalah pahaman dalam agama menimbulkan gerakan radikal. Kebiasan dalam stigma Radikalisme, suatu kelompok akan menuduh kelompok lain sebagai kelompok

\footnotetext{
${ }^{7}$ Lihat Ulyan Nasri, Ngaji Bareng Filosof: Sebuah Pengantar Filsafat Umum (Mataram: CV. Haramain Lombok, 2020), 65 .

${ }^{8}$ Baca Ulyan Nasri, Philosophy is Mother of Science: Pengantar Filsafat (Mataram: CV. Haramain Lombok, 2020)., 78. Bandingkan Ulyan Nasri, Ngaji Bareng Filosof: Sebuah Pengantar Filsafat Umum (Mataram: CV. Haramain Lombok, 2020), 53.
} 
radikal, belum ada standar yang jelas dalam penilaian kapan suatu kelompok atau pribadi tertentu disebut sebagai orang atau kelompok yang berpaham radikal. Selama ini wewenang penilaian selalu diserahkan pada presepsi media masa atau pengaruh kekuatan politik. Hal tersebut bisa dibuktikan dengan membaca sejarah radikalisme dari masa ke masa. "Namun perlu kita ketahui bahwa tuduhan radikalisme untuk umat Islam baru dikenal beberapa tahun belakangan ini. Diawali sejak perang dingin antara dua negara adikuasa berakhir, setelah kalahnya adikuasa Uni Soviet dalam melawan Afganistan. Lalu negara-negara Islam yang berada dalam cengkraman negara tersebut berusaha melepaskan diri. Kemudian lebih mengemuka lagi setelah kejadian 11 September di Amerika Serikat tahun 2001.

Akan tetapi suatu hal yang sangat mengherankan sekaligus memalukan adanya pernyataan dari salah seorang yang dianggap sebagai tokoh Islam bahwa ciri kelompok Radikalisme adalah jenggotan, celana cingkrangan dan selalu membawa mushaf kecil. Hal ini menunjukkan keterbelakangan tokoh tersebut dalam segi informasi dan pemikiran apa lagi tentang pemahaman ajaran agama. Pernyataan tersebut di samping tidak sesuai dengan fakta juga terselip bentuk kebencian terhadap umat Islam yang berusaha menjalan agamanya sesuai dengan yang diperintahkan Rasûlullâh Shallallahu 'alaihi wa sallam.

Berangkat dari beberapa hal di atas menjadi sebuah kegelisahan akademik tulisan ini, sehingga tema yang menarik untuk dianalisis tentang, "Menakar Kembali Materi Pendidikan Agama Islam Untuk Menangkal Tuduhan Faham Radikalisme Kepada Umat Islam."

\section{Radikalisme Secara Historis}

Dalam wikipedia disebutkan: Radikalisme dapat merujuk kepada: Radikalisme (sejarah), sebuah kelompok atau gerakan politik yang kendur dengan tujuan mencapai kemerdekaan atau pembaruan elektoral yang mencakup mereka yang berusaha mencapai republikanisme, penghapusan gelar, redistribusi hak milik dan kebebasan pers, dan dihubungkan dengan perkembangan liberalisme. "Menurut Encyclopædia Britannica, kata "radikal" dalam konteks politik pertama kali digunakan oleh Charles James Fox. Pada tahun 1797, ia mendeklarasikan "reformasi radikal" sistem pemilihan, sehingga istilah ini digunakan untuk mengidentifikasi pergerakan yang mendukung reformasi parlemen." 9

Radikalisme dapat mengacu kepada beberapa hal berikut: Ekstremisme, dalam politik berarti tergolong kepada kelompok-kelompok radikal kiri, Ekstrem kiri atau Ekstrem kanan. Radikalisasi, transformasi dari sikap pasif atau aktivisme kepada sikap yang lebih radikal, revolusioner, ekstrem, atau militan. Sementara istilah "Radikal" biasanya dihubungkan dengan gerakan-gerakan ekstrem kiri, "Radikalisasi" tidak membuat perbedaan seperti itu.

\footnotetext{
${ }^{9}$ https://id.wikipedia.org/wiki/Radikalisme. diakses hari selasa, 5 februari 2020. Jam 11.59.
} 
Dalam pengertian khusus: Radikalisme (historis), sebuah kelompok atau gerakan politik yang kendur dengan tujuan mencapai kemerdekaan atau pembaruan elektoral yang mencakup mereka yang berusaha mencapai republikanisme, penghapusan gelar, redistribusi hak milik dan kebebasan pers, dan dihubungkan dengan perkembangan liberalisme. Partai Radikal - sejumlah organisasi politik yang menyebut dirinya Partai Radikal, atau menggunakan kata Radikal sebagai bagian dari namanya. Dalam kenyataan sejarah pihak yang berkuasa atau pihak yang tidak mau kekuatannya dilemahkan selalu menuduh pihak yang lemah sebagai kaum radikal. Sedangkan sikap radikal mereka terhadap orang lain tidak dinilai sebagai tindakan radikal.

Radikalisme dalam Islam bisa dikatakan sebagai perilaku keagamaan yang menghendaki perubahan secara drastis dengan mengambil karakter keras yang bertujuan untuk merealisasikan tujuan-tujuan tertentu di tinjau dari naluri. Dan apabila di tinjau dari prilaku yaitu tidak mau tunduk pada pemerintahan yang sah. Dalam kesejarahan Islam, fenomena radikalisme dalam Islam sudah berlangsung sejak wafatnya Nabi Muhammad shallahu 'alaihi wasallam. Pergantian setiap khalifah hingga permusuhan Ali dan Muawiyah mewarnai dunia perpolitikan Islam. Permusuhan Ali dan Muawiyah melahirkan arbitrase antar keduanya. Dari sikap Ali tersebut, ada sebagian kelompok yang menentangnya, yang kemudian kelompok ini menamakan dirinya Khawarij yang didirikan oleh Dhu alKhuwaysirah. ${ }^{10}$ Kelompok Khawarij ini menganggap Ali dan Muawiyah melakukan dosa besar, sampai pada kesimpulan bahwa darah mereka halal untuk dibunuh. ${ }^{11}$

Tumbuhnya gerakan radikalisme di Indonesia tidak hanya dari dalam melainkan juga dibarengi dengan adanya ilfiltrasi dari luar. Sebagaimana yang ditunjukkan oleh Barton bahwa gerakan Wahabi mulai tumbuh tidak lepas dari peran Muhammad Natsir. Melalui organisasi yang dibangun Natsir yakni Dewan Dakwah Islam Indonesia berhasil memberikan beasiswa kepada mahasiswa untuk melanjutkan jenjang pendidikan di universitas Ibn Saud. Dalam perkembangannya, DDII bekerjasama dengan universitas tersebut untuk mendirikan Lembaga Pengetahuan Bahasa Arab-LPBA atau lebih dikenal LIPIA. ${ }^{12}$ Salah satu lulusan yang terkenal dari LIPIA adalah Ja'far Umar Thalib, pendiri dan pimpinan Forum Komunikasi Ahlusunnah Wal-Jamaah (FKAWJ). Dari fenomena Darul Islam dan LIPIA menjadi cikal bakal tumbuh kembangnya Islam radikal di Indonesia, baik secara struktural maupun kultural. Namun perlu dicatat bahwa gerakan ideologi politik Islam

${ }^{10}$ Ahmad Choirul Rofiq, “Awal Radikalisme Islam: Penyebab Kemunculan Khawarij”, Al-Tahrir, vol. 14, no. 1, Mei 2014. 229.

${ }^{11}$ Jajar Zarkasy \& Thobib Al-Asyhar, Radikalisme Agama dan Tantangan Kebangsaan, (Jakarta: Direktorat Jendral Bimas Islam Kemenag RI, 2014), 6.

${ }^{12}$ Greg Barton in The Combating Terorrism at West Point Radical Islamic Ideology in Southeast Asia, Scott Helfstein (ed), Southeast Asia Project, 2009, 36. 
mengalami titik terendah pada masa Orde Baru ketika rezim semakin otoriter dan melakukan marginalisasi Islam. Represi baru yang semakin meluas itu terjadi pada tahun 1985 ketika pemerintah menetapkan kewajiban asas tunggal Pancasila bagi organisasi kemasyarakatan melalui Undang-Undang No. 8/1985 yang semakin menimbulkan ketegangan dengan kalangan Islam. ${ }^{13}$ Pada periode represi ini sebenarnya kelompok-kelompok Islam ideologis tidak sungguh-sungguh mati, karena keyakinan dan orientasi ideologis dalam setiap gerakan, lebih-lebih keagamaan, biasanya tidak mudah untuk ditumpas. Kelompok dan tokoh-tokoh Islam yang secara terang-terangan menentang pemaksaan penyeragaman ideologi dan politik ala Orde Baru adalah Ustadz Abdullah Sungkar dan Abu Bakar Baasyir yang dikenal sebagai pemimpin Jamaah Islamiyah.

\section{Penegasan Kembali arti Pendidikan Agama Islam}

Pendidikan adalah Proses sepanjang hayat dan perwujudan pembentukan diri secara utuh. Aktivitas pendidikan dapat berlangsung dalam keluarga, sekolah dan masyarakat. Dapat diambil benang merahnya dari pengertian pendidikan tersebut bahwa unsur-unsur pendidikan terdiri dari; pembinaan kepribadian, pengembangan potensi dan peningkatan dari tidak tahu menjadi tahu. ${ }^{14}$

Menelisik kembali pengertian Pendidikan Agama Islam pada umumnya mengacu kepada term al-Tarbiyah, al-Ta'dỉb, dan al-Ta'limm. ${ }^{15}$ Dari ketiga istilah tersebut term yang popular digunakan dalam praktik Pendidikan Islam ialah term al-Tarbiyah, sedangkan term al-Ta'dỉ dan al- Ta'lim jarang sekali digunakan.Terlepas dari perbedaan penggunaan term yang tiga ini (al-Tarbiyah, al-Ta'dīb, dan al-Ta'lim), makna dari ketiga term di atas, secara terminologi, para ahli pendidikan Islam telah mencoba menformulasikan pengertian Pendidikan Islam. Di antara batasan yang sangat variatif tersebut adalah:

a. Zakiah Darajat menjelaskan pendidikan Agama Islam adalah usaha berupa bimbingan dan asuhan terhadap anak didik agar kelak setelah selesai pendidikannya dapat memahami dan mengamalkan ajaran Agama Islam serta menjadikannya sebagai pandangan hidup (way of life). Yang dilaksanakan berdasarkan ajaran Agama Islam. Serta menjadikan ajaran Agama Islam itu sebagai suatu pandangan hidupnya demi keselamatan hidup di dunia maupun di akhirat kelak. ${ }^{16}$

\footnotetext{
${ }^{13}$ Haedar Nashir, Islam Syarikat (Jakarta: Mizan, 2013), 279.

${ }^{14}$ Ulyan Nasri, "Shalat Ditinjau dari Sudut Pandang Pendidikan, Sosial dan Politik". Juranal al-Munawwarah: Jurnal Pendidikan Islam. Vol. 10, No. 1. tahun 2018, 46.

${ }^{15}$ Ulyan Nasri, "Perempuan Perempuan: Memotret Bias Gender dalam Konteks Sosio-Kultural Lombok menuju sebuah Humanisme Sosial-Spiritual”. Juranal al-Munawwarah: Jurnal Pendidikan Islam. Vol. 10, No. 2. tahun $2018,25$.

${ }^{16}$ Zakiah Darajat, Metodik Khusus Pengajaran Agama Islam (Jakarta: Bumi Aksara, 1995 ), 50.
} 
b. Ahmad Tafsir mendefinisikan Pendidikan Islam sebagai bimbingan yang diberikan oleh seseorang kepada seseorang agar ia berkembang secara maksimal sesuai dengan ajaran Islam. Bila disingkat, Pendidikan Islam ialah bimbingan terhadap seseorang agar ia menjadi Muslim semaksimal mungkin. ${ }^{17}$

c. Achmadi memberikan penjelasan bahwa yang dimaksud dengan Pendidikan Islam adalah segala usaha untuk memelihara dan mengembangkan fitrah manusia serta sumber daya manusia yang ada padanya menuju terbentuknya manusia seutuhnya (insān kamīl) sesuai dengan norma Islam. ${ }^{18}$

d. Zuhairini, Pendidikan Agama Islam adalah usaha sadar, yakni kegiatane. Zuhairini, Pendidikan Agama Islam adalah usaha sadar, yakni kegiatan bimbingan ke arah pembentukan kepribadian peserta didik secara sistematis dan pragmatis, supaya sesuai dengan ajaran Islam, sehingga terjadinya kebahagiaan dunia dan akhirat. ${ }^{19}$

Jelaslah bahwa proses kependidikan merupakan rangkaian usaha membimbing, mengarahkan potensi hidup manusia yang berupa kemampuan belajar, sehingga terjadilah perubahan di dalam kehidupan pribadinya sebagai makhluk individu dan sosial serta dalam hubungannya dengan alam sekitar di mana ia hidup. Proses tersebut senantiasa berada dalam nilai-niolai Islami, yaitu nilai-nilai yang melahirkan norma-norma syariah dan akhlak al-karimah. ${ }^{20}$

Hemat penulis berangkat dari beberapa pengertian pendidikan dan pendidikan Islam di atas sedikit pun tidak ada materi yang mengarah kepada tindakan radikalisme, kekerasan, teroris dan ekstrimis. Jadi, tuduhan radilisme dalam Islam terbantahkan dan jelas merupakan klaim yang tidak benar. Karena ajaran Islam mengandung ajaran yang humanis-pluralis dan cenderung toleran kepada agama lain. dalam al-Qur'an telah ditegaskan dalam banyak ayatnya. ${ }^{21}$

\section{Radikalisme secara Etimologi dan Terminologi}

Radikal berasal dari kata 'radix' yang berarti akar, dan radikal adalah (sesuatu) yang bersifat mendasar atau hingga akar-akarnya. Predikat ini bisa dikenakan pada pemikiran atau paham tertentu.sehingga muncul istilah pemikiran yang radikal dan bisa pula gerakan. Berdasarkan hal itu, radikalisme diartikan dengan paham atau aliran keras yang

\footnotetext{
${ }^{17}$ Ahmad Tafsir, Ilmu Pendidikan dalam Perspektif Islam (Bandung: Remaja Rosdakarya, 1992), 32.

${ }^{18}$ Achmadi, Ideologi Pendidikan Islam Paradigma HumanismeTeosentris (Yogyakarta: PustakaPelajar, 2005), 31.

${ }^{19}$ Zakiah Darajat, Pendidikan Agama Islam (Solo: Ramadhani, 1993), 11.

${ }^{20}$ Muzayyin Arifin, Filsafat Pendidikan Islam (Jakarta: Bumi Aksara, 2014), 15.

${ }^{21}$ Ulyan Nasri, "Pemikiran Tuan Guru Kyai Haji Muhammad Zainuddin Abdul Madjid Tentang Pendidikan Islam Perempuan Dan Implementasinya Di Madrasah Nahdlatul Banat Diniyah Islamiyah Lombok." (Tesis Pascasarjana UIN Sunan Kalijaga, 2014), 4-5.
} 
menginginkan perubahan atau pembaruan sosial dan politik dengan cara keras atau drastic dan sikap ekstrem suatu aliran politik. ${ }^{22}$

Yusuf al-Qardhawi memberikan istilah radikalisme dengan istilah al-Tatarruf adDin. Atau bahasa lugasnya adalah untuk mempraktekkan ajaran agama tidak semestinya, atau mempraktekkan ajaran agama dengan mengambil posisi Tarf atau pinggir. Jadi jauh dari substansi ajaran agama Islam. Yaitu ajaran moderat di tengah-tengah. Biasanya posisi pinggir ini adalah sisi yang berat atau memberatkan dan berlebihan, yang tidak sewajarnya. Apa makna dari implikasi cara beragama seperti ini, ialah bahwa dalam praktek pengalaman beragama terdapat orang-orang berperilaku ekstrim, sehingga melebihi keawajaran yang seme

stinya. ${ }^{23}$

Radikalisme dapat dibedakan ke dalam dua level, yaitu level pemikiran dan level tindakan atau aksi. Pada level pemikiran, radikalisme masih berupa wacana konsep dan gagasan yang masih diperbincangkan, yang intinya mendukung penggunaan cara-cara kekerasan untuk mencapai tujuan. Adapun pada level aksi atau tindakan, radikalisme bisa berada pada ranah sosial, politik dan agama. Pada ranah politik faham ini Nampak tercermin dari adanya tindakan memaksakan pendapatnya dengan cara-cara yang inskontitusional, bahkan bisa berupa tindakan mobilisasi masa untuk kepentingan politik tertentu dan berujung pada konflik sosial. ${ }^{24}$

Ketika agama telah memasuki ranah ideologi, maka ketika itu agama telah menjadi bagian dari kebenaran yang harus dipertahankan dan diperjuangkan dengan berbagai cara termasuk cara-cara yang hakikatnya melawan teks agama itu sendiri. Perusakan, pembakaran, penghancuran, dan pengeboman atas nama agama yang dilakukan dengan mengucapkan Takbir (Allahu Akbar) adalah sekelumit kisah tentang wajah agama dengan tafsir agama yang keras, radikal atau fundamental. ${ }^{25}$

\section{Pendidikan Agama Islam dan Penanggulangan Radikalisme}

Penyelenggaraan pendidikan di Indonesia menurut UU Nomor 20 Tahun 2003 pasal 1 ayat (2) disebutkan bahwa suatu Pendidikan Nasional adalah pendidikan yang berdasarkan Pancasila dan Undang-Undang Dasar 1945 yang berakar pada nilai-nilai agama,

\footnotetext{
${ }^{22}$ Imam Tayibi, dkk, "Radikalisme Agama Sebagai Salah Satu Bentuk Perilaku Menyimpang” Jurnal Kriminologi Indonesia, Vol.3 No.1 (Juni:2003), .45

${ }^{23}$ Anzar Abdullah, "Gerakan Radikalisme dalam Islam Perspektif Historis", Jurnal ADDIN, Vol.10.No.1 (Februari, 2016), 5 .

${ }^{24}$ Abdul Munip, “Menangkal Radikalisme Agama di Sekolah”, Jurnal Pendidikan Islam,Vol.1 No. 2 (Desember 2012), 162

${ }^{25}$ Nur Syam, Tantangan Multiklturalisme Indonesia dari Radikalisme Menuju Kebangsaan, (Yogyakarta: Kansius, 2009), 132
} 
kebudayaan nasional Indonesia dan tanggap terhadap tuntutan perubahan zaman ${ }^{26}$ Tidak bisa dipungkiri bahwa pendidikan Islam, baik sebagai sistem maupun insitusinya, merupakan warisan budaya bangsa, yang berurat berakar pada masyarakat bangsa Indonesia. Dengan demikian jelas bahwa pendidikan Islam akan merupakan bagian integral dari system pendidikan nasional.

Kebutuhan akan pendidikan merupakan hal yang tidak bisa dipungkiri, bahkan semua itu merupakan hak semua warga Negara, berkenaan dengan ini, di dalam UUD'45 Pasal 31 ayat (1) secara tegas disebutkan bawha; “Tiap-tiap warga Negara berhak mendapat pengajaran". Tujuan pendidikan nasional dinyatakan dalam UU RI No. 20 Tahun 2003 Pasal 3 bertujuan untuk berkembangnya potensi peserta didik agar menjadi manusia yang beriman dan bertaqwa kepada Tuhan Yang Maha Esa, berakhlak mulia, sehat, berilmu, cakap, kreatif mandiri, dan menjadi warga Negara yang demokratis serta bertanggung jawab. Tujuan pendidikan nasional suatu bangsa menggambarkan manusia yang baik menurut pandangan hidup yang dianut oleh bangsa itu, dan tujuan pendidikan sesuatu bangsa mungkin tidak akan sama dengan bangsa lainnya, karena pandangan hidup mereka biasanya tidak akan sama. ${ }^{27}$ Tetapi pada dasarnya pendidikan setiap bangsa tentu sama, yaitu semua menginginkan terwujudnya manusia yang baik yaitu manusia yang sehat, kuat serta mempunyai ketrampilan, pikirannya cerdas serta pandai, dan hatinya berkembang dengan sempurna. Pendidikan pada dasarnya suatu upaya terus menerus yang bertujuan mengembangkan seluruh potensi kemanusiaan peserta didik dalam mempersiapkan mereka agar mampu menghadapi menghadapi berbagai tantangan dalam kehidupannya. Dengan demikian, di satu sisi pendidikan merupakan sebuah upaya penanaman nila-nilai kepada peserta didik dalam rangka membentuk watak dan kepribadiannya. Selanjutnya, pendidikan mendorong peserta didik untuk mewujudkan nilai-nilai tersebut ke dalam perilaku dalam kehidupan sehari-hari. ${ }^{28}$ Sedangkan Pendidikan Agama Islam mempunyai fungsi sebagaimana Menurut Kurshid Ahmad, adalah sebagai berikut: Pertama: Alat untuk memelihara, memperluas dan menghubungkan tingkat-tingkat kebudayaan, nilai-nilai tradisi dan sosial, serta ide-ide masyarakat dan bangsa. Kedua: Alat untuk mengadakan perubahan, inovasi dan perkembangan yang secara garis besarnya

\footnotetext{
${ }^{26}$ Hasbullah, Dasar-dasar Ilmu Pendidikan, (Jakarta, PT Raja Grafindo Persada, 2005) Cet ke-4, 174

${ }^{27}$ Hasbullah, Dasar-dasar Ilmu Pendidikan, ... 310.

${ }^{28}$ Abdul Rahman Shaleh, Pendidikan Agama dan Pembangunan Watak Bangsa (Jakarta: PT Raja Grafindo Persada, 2006), 259.
} 
melalui pengetahuan dan skill yang baru ditemukan, dan melatih tenaga-tenaga manusia yang produktif untuk menemukan perimbangan perubahan sosial dan ekonomi. ${ }^{29}$

Sesuai dengan hakikat Pendidikan Islam yang merupakan suatu proses yang berlangsung secara kontiniu atau berkesinambungan, maka tugas dan fungsi yang diemban oleh Pendidikan Islam adalah pendidikan manusia seutuhnya dan berlangsung sepanjang hayat. Konsep ini bermakna bahwa tugas dan fungsi pendidikan memiliki sasaran pada peserta didik yang senantiasa tumbuh dan berkembang secara dinamis, sejak masih dalam kandungan sampai ajal menjemputnya.Secara umum tugas Pendidikan Islam adalah membimbing dan mengarahkan pertumbuhan dan perkembangan peserta didik dari tahap ke tahap kehidupannya sampai mencapai titik kemampuan yang optimal sesuai dengan tuntutan ajaran Islam. ${ }^{30}$

Kelompok radikalisme menurut Yusuf al Qardhawi memiliki ciri-ciri antara lain: Pertama: Sering mengklaim kebenaran tunggal dan menyesatkan kelompok lain yang tidak sependapat, Kedua: Radikalisme mempersulit agama Islam yang sejatinya samhah (ringan) dengan menganggap pekerjaan sunah adalah wajib dan makruh seakan-akan haram. Ketiga: Kelompok radikal kebanyakan berlebihan dalam beragama yang tidak ada tempatnya. Keempat: Kasar dalam berinteraksi, keras dalam berbicara dan emosional dalam berdakwah, Kelima: Mudah berburuk sangka kepada orang laindi luar golongannya. 6) Mudah mengkafirkan orang lain yang berbeda pendapat. ${ }^{31}$

Penyebab munculnya radikalisme Islam, di sebabkan beberapa hal berikut ini: Pertama: Pemahaman agama yang literal, memahami ayat sepotong-potong. Kedua: Bacaan yang salah terhadap sejarah Islam yang dikombinasikan dengan idealisasi berlebihan terhadap Islam pada masa tertentu. Ketiga: Deprivasi politik, sosial dan ekonomi yang masih bertahan dalam masyarakat. Keempat: Mudah terpengaruhnya umat Islam terhadap paham baru tanpa diikuti dengan sikap kritis dalam meyakininya. ${ }^{32}$

Pembelajaran Pendidikan Agama Islam Non Radikalisme Misi ajaran Islam yang sebenarnya sangat luhur dan mulia sering kali Mengalami distorsi akibat pemahaman

\footnotetext{
${ }^{29}$ Abdul Mujib dan Jusuf Mudzakkir, Ilmu Pendidikan Islam (Jakarta, PrenadaMedia. 2006), 69.

${ }^{30}$ Al-Rasyidin dkk, Pendekatan Historis, Teoritis dan Praktis Filsafat Pendidikan Islam (Jakarta: Ciputat Press, 2005), 32 .

${ }^{31}$ Irwan Masduqi, "Deradikalisme Pendidikan Islam Berbasis Khazah Pesantren”, Jurnal Pendidikan Islam, Vol.1, No.2, (Desember 2012), 3-4.

${ }^{32}$ Abdul Munip, "Menangkal radikalisme Agama di Sekolah", Jurnal Pendidikan Islam, Vol.1, No.2, (Desember 2012), 163-164.
} 
yang keliru terhadap beberapa aspek ajaran Islam yang berpotensi menimbulkan faham radikalisme. Beberapa di antaranya adalah: 33

1) Penjelasan tentang jihad. Jihad adalah konsep ajaran Islam yang paling sering menimbulkan kontroversi dikalangan umat. Bagi kaum radikalis, jihad selalu bermakna qitâl atau peperangan atau perjuangan dengan mengangkat senjata. Sebenarnya makna jihad mempun yai arti yang beragam meskipun salah satunya perang melawan musuh Islam. Ada beberapa pengertian Jihad: (a) Perang, (b) Haji Mabrur, (c) Menyampaikan kebenaran kepada penguasa yang dzalim, (d) Berbakti kepada orang tua, (e) Menuntut ilmu dan mengembangkan pendidikan, (f) Membantu fakir dan miskin.

2) Menjelaskan tentang toleransi. Ajaran Islam sebenarnya syarat dengan toleransi. Namun toleransi sering dipahami secara sempit, sehingga tidak mampu menjadi perekat intra dan antar umat beragama.

3) Pengenalan tentang hubungan ajaran Islam dengan kearifan local, Islam yang turun di aran bukanlah Islam uang bebas dari sejarah local yang mengitarinya. Artinya memahami Islam tidak bisa dipisahkan dari akar sosio-historis di mana Islam berada.

\section{Strategi Pembelajaran Pendidikan Agama Islam Non Radikalisme}

\section{1) Strategi Pembelajara Inklusif}

Pendidikan Islam mempunyai peran yang strategis dalam membangun inklusivitas dan sekaligus memberantas eksklusivitas keagamaan di Indonesia. hal ini dikarenakan pendidikan media yang paling efektif dan efisien dalam upaya melakukan penanaman nilai-nilai kemanusiaan dan religious kepada peserta didik. Pendidikan Islam yang lebih menekankan pada aspek doktriner normatif cenderung melahirkan sikap eksklusifliteralis. Sikap eksklusif cenderung berusaha memonopoli kebenaran, tidak mau mendengar dan dan memahami orang lain serta kecenderungan bersikap otoriter. Kecenderungan ini memperlihatkan mudahnya seseorang menghukumi orang lain dengan kejam dan tidak manusiawi, hal inilah yang menjadi salah satu fakor awal sikap radikal yang berujung pada aksi terror. ${ }^{34}$ Dalam menghadapi pluralitas masyarakat yang multi etnik dan multi religi dibutuhkan pendidikan Islam yang inklusif yang berorientasi pada kesalehan sosial dengan tidak melupakan kesalehan individual. Inklusif adalah sikap berfikir terbuka dan menghargai perbedaan dalam bentuk pendapat, pemikiran, etnis,

${ }^{33}$ Sjuhada Abduh dan Nahar Nahrawi, "Makna Jihad dan Respon Komunitas Muslim Serang Pasca Eksekusi Imam Samudra”, Jurnal Harmoni, Vol.VIII, No.32, (Oktomber 2009), 113-130.

${ }^{34}$ Khamdan dkk, Strategi Pembelajaran Pendidikan Agama Islam di sekolah; Teori Metodologi dan Implementasi (Yogyakarta;Idea press, 2012), 182-183. 
tradisi budaya hingga perbedaan agama. Dalam al-Qur'an telah dijelaskan dalam ayat berikut ini:

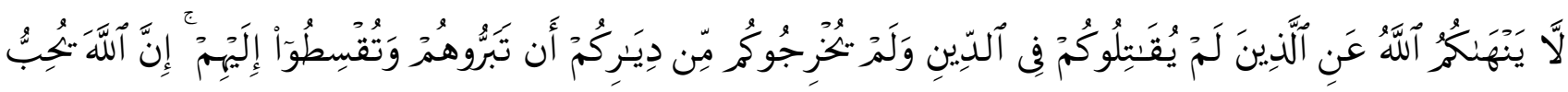

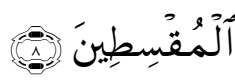

"Allah tiada melarang kamu untuk berbuat baik dan berlaku adil terhadap orang-orang yang tiada memerangimu karena agama dan tidak (pula) mengusir kamu dari negerimu. Sesungguhnya Allah menyukai orang-orang yang berlaku adil" (QS. Al-Mumtahah 60: 8)

Berangkat dari ayat di atas, menjadi rujukan yang jelas bahwa Islam tidak mengajarkan terorisme bagi pemeluknya. Dalam ayat di atas cenderung memerintahkan sikap toleransi kepada agama selain Islam selama mereka tidak memerangi dan menindas lebih dulu. Dalam ayat yang lain:

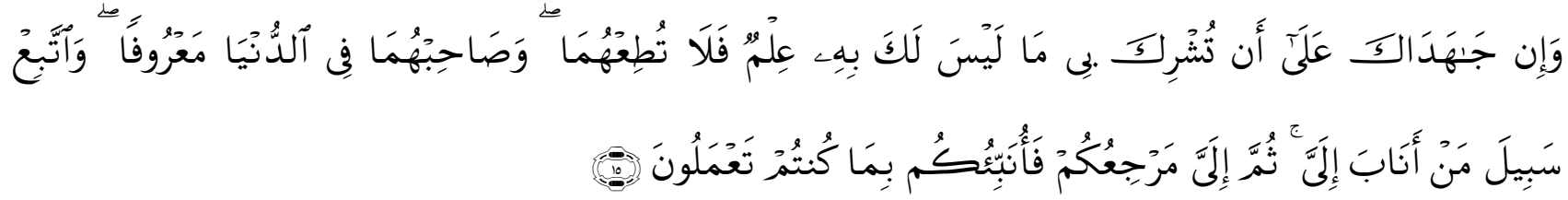

Dan jika keduanya memaksamu untuk mempersekutukan dengan aku sesuatu yang tidak ada pengetahuanmu tentang itu, Maka janganlah kamu mengikuti keduanya, dan pergaulilah keduanya di dunia dengan baik, dan ikutilah jalan orang yang kembali kepada-Ku, kemudian hanya kepadaKulah kembalimu, Maka Kuberitakan kepadamu apa yang telah kamu kerjakan. (QS. Luqman 31:15).

Sederhananya, jika agama lain di luar agama Islam yang tidak percaya kepada ajaran Islam, maka prilaku yang harus diperbuat adalah prilaku baik, karena bisa jadi dengan menonjolkan prilaku baik, diharapkan mereka tertarik untuk masuk Islam. Inilah yang dilakukan oleh Rasulullah shallahu 'alaihi wasallam.

\section{2) Strategi Pembelajaran kontekstual}

Strategi pembeljaran kontekstual merupakan strategi pembelajaran yang mengaitkan materi yang diajarkan dengan kehidupan nyata. pembelajaran ini memotivasi peserta didik menghubungkan materi yang diperoleh dengan penerapan dalam kehidupan nyata. Dengan konsep ini diharapkan hasil pembelajaran lebih bermakna. Proses pembelajaran berlangsung alamiah dalam bentuk kegiatan peserta didik bekerja dan mengalami, bukan 
mentransfer pengetahuan dari guru ke peserta didik. ${ }^{35}$ Strategi pembelajaran Kontekstual bersumber dari pendekatan kontruktivis. Menurut teori belajar kontruktivis, bahwa individu belajar dengan cara mengkontrusi makna melalui interaksi dengan lingkungannya kemudian menginterpretasikannya. Pada intinya pembelajaran pendidikan agama Islam secara kontekstual selalu mengkaitkan pembelajaran PAI dengan konteks dan pengalaman-pengalaman hidup peserta didik yang beraneka ragam dan konteks-konteks masalah serta situasi-situari riil kehidupan. ${ }^{36}$

\section{Kesimpulan}

Islam adalah agama yang mengajarkan humanisme-toleran kepada agama lain selama agama lain tidak mengganggu dan memerangi terlebih dahulu. Sikap inilah yang harus diinternalisasikan dalam materi pendidikan agama Islam supaya peserta didik tidak mudah dipengaruhi oleh faham radikalisme. Pendidikan Agama Islam adalah upaya sadar dan terencana dalam menyiapkan peserta didik untuk mengenal, memahami, menghayati, hingga mengimani ajaran Agama Islam dibarengi dengan tuntunan untuk menghormati penganut agama lain dalam hubungannya dengan kerukunan antarumat beragama hingga terwujud kesatuan persatuan bangsa. Adapun istilah Radikalisme diartikan dengan paham atau aliran keras yang menginginkan perubahan atau pembaruan sosial dan politik dengan cara keras atau drastis dan sikap ekstrem suatu aliran politik. Maka, untuk mengantisipasi peserta didik dari faham radikalisme tersebut, dipandang perlu menakar kembali nilai-nilai ajaran Islam yang mengandung nilai humanis dan toleran. Beberapa materi Pendidikan Agama Islam (PAI) dalam Penanggulangan Radikalisme yang harus menjadi perhatian para guru yaitu: (1) Memberikan Pembelajaran Pendidikan Agama Islam Non Radikalisme, di antaranya adalah: (a) Penjelasan tentang jihad. (b) Menjelaskan tentang toleransi. (c) Pengenalan tentang hubungan ajaran Islam dengan kearifan local, - Memberikan Strategi Pembelajaran Pendidikan Agama Islam Non Radikalisme, yakni; (a) Strategi Pembelajara Inklusif. (b) Strategi Pembelajaran kontekstual.

\section{Daftar Pustaka}

Abdul Mujib dan Jusuf Mudzakkir, Ilmu Pendidikan Islam, Jakarta, PrenadaMedia. 2006.

Abdul Munip, "Menangkal Radikalisme Agama di Sekolah", Jurnal Pendidikan Islam,Vol.1 No. 2, Desember 2012.

Abdul Munip, "Menangkal radikalisme Agama di Sekolah", Jurnal Pendidikan Islam, Vol.1, No.2,

Desember 2012.

\footnotetext{
${ }^{35}$ Sumartana, Pluralisme Konflik dan Pendidikan Agama di Indonesia (Yoyakarta Interfidei 2001), 252.

${ }^{36}$ Muhaimin, Rekontruksi Pendidikan Islam, (Jakarta: PT Raja Grafindo Persada, 2009), 261-262.
} 
Tarbawi, Volume 5 No. 12020

Ulyan Nasri, Menakar Kembali Materi Pendidikan...

Abdul Rahman Shaleh, Pendidikan Agama dan Pembangunan Watak Bangsa, Jakarta: PT Raja Grafindo Persada, 2006.

Achmadi, Ideologi Pendidikan Islam Paradigma HumanismeTeosentris, Yogyakarta: PustakaPelajar, 2005.

Ahmad Choirul Rofiq, "Awal Radikalisme Islam: Penyebab Kemunculan Khawarij", Al-Tahrir, vol. 14, no. 1, Mei 2014.

Ahmad Tafsir, Ilmu Pendidikan dalam Perspektif Islam, Bandung: Remaja Rosdakarya, 1992.

Al-Rasyidin dkk, Pendekatan Historis, Teoritis dan Praktis Filsafat Pendidikan Islam, Jakarta:

Ciputat Press, 2005.

Anzar Abdullah, "Gerakan Radikalisme dalam Islam Perspektif Historis", Jurnal ADDIN, Vol.10.No.1, Februari, 2016.

B.Kusumohamidjojo, Kebinekaan Masyarakat Indonesia; Suatu Problematik Filsafat Kebudayaan, Jakarta; Grasindo, 2000.

Greg Barton in The Combating Terorrism at West Point Radical Islamic Ideology in Southeast Asia, Scott Helfstein (ed), Southeast Asia Project, 2009.

Haedar Nashir, Islam Syarikat, Jakarta: Mizan, 2013.

Hasbullah, Dasar-dasar Ilmu Pendidikan, Jakarta, PT Raja Grafindo Persada, 2005.

https://id.wikipedia.org/wiki/Radikalisme.

Imam Tayibi, dkk, "Radikalisme Agama Sebagai Salah Satu Bentuk Perilaku Menyimpang" Jurnal Kriminologi Indonesia, Vol.3 No.1, Juni:2003.

Irwan Masduqi, "Deradikalisme Pendidikan Islam Berbasis Khazah Pesantren", Jurnal Pendidikan Islam, Vol.1, No.2, Desember 2012.

Jajar Zarkasy \& Thobib Al-Asyhar, Radikalisme Agama dan Tantangan Kebangsaan, Jakarta:

Direktorat Jendral Bimas Islam Kemenag RI, 2014.

Khamdan dkk, Strategi Pembelajaran Pendidikan Agama Islam di sekolah; Teori Metodologi dan Implementasi, Yogyakarta;Idea press, 2012.

Moh.Roqib, Ilmu Pendidikan Islam Pengembangan pendidikan Integratif di Sekolah Keluarga dan Masyarakat, Yogyakarta;LKis, 2009.

Muhaimin, Rekontruksi Pendidikan Islam, Jakarta: PT Raja Grafindo Persada, 2009.

Muzayyin Arifin, Filsafat Pendidikan Islam, Jakarta: Bumi Aksara, 2014.

Nur Syam, Tantangan Multiklturalisme Indonesia dari Radikalisme Menuju Kebangsaan, Yogyakarta: Kansius, 2009.

Sjuhada Abduh dan Nahar Nahrawi, “Makna Jihad dan Respon Komunitas Muslim Serang Pasca Eksekusi Imam Samudra”, Jurnal Harmoni, Vol.VIII, No.32, Oktomber 2009.

Sumartana, Pluralisme Konflik dan Pendidikan Agama di Indonesia, Yoyakarta Interfidei 2001. 
Tarbawi, Volume 5 No. 12020 Ulyan Nasri, Menakar Kembali Materi Pendidikan...

Syamsul arifin, Studi Islam Kontemporer; Arus Radikalisme dan Multikulturalisme di Indonesia, Malang: Intrans Publising, 2015.

Ulyan Nasri, Bersahabat dengan Ilmu: Sebuah Pengantar Filsafat Ilmu, Mataram: CV. Haramain Lombok, 2018.

, Mengenal Ahl al-Sunnah wa al-Jama'ah dalam Konteks Nahdlatul Wathan, Mataram: CV. Haramain Lombok, 2019.

, Menjemput Ilmu: sebuah Pengantar Filsafat Ilmu, Yogyakarta: Semesta Ilmu, 2016

, Ngaji Bareng Filosof: Sebuah Pengantar Filsafat Umum, Mataram: CV. Haramain Lombok, 2020.

, Philosophy is Mother of Science: Pengantar Filsafat, Mataram: CV. Haramain Lombok, 2020.

- Shalat Ditinjau dari Sudut Pandang Pendidikan, Sosial dan Politik. Juranal alMunawwarah: Jurnal Pendidikan Islam. Vol. 1, No. 4. tahun 2018.

Zakiah Darajat, Metodik Khusus Pengajaran Agama Islam, Jakarta: Bumi Aksara, 1995.

Zakiah Darajat, Pendidikan Agama Islam, Solo: Ramadhani, 1993. 